\title{
Headscarf in the Context of Precarious Work: A Critical Approach to the Headscarf Discussion in Turkey
}

\author{
Feyda Sayan-Cengiz
}

This study examines the role and meaning of the headscarf in the working lives of lower-middle class saleswomen without a university degree. The focus is on how lower middle class women with headscarves working in sales jobs relate to the Islamic identity that is associated with the headscarf, and how they handle the connotations of the headscarf in the context of their precarious, insecure, lowpaid, temporary jobs. Much has been written about the politics of difference revolving around the headscarf in Turkey, especially with regard to the exclusion of the headscarf from the state monitored public sphere, as well as the political struggle of educated women with headscarves against this exclusionary, homogenizing public sphere. I investigate the relevance of the arguments formulated through a politics of difference framework in the context of lower middle class women's working lives. More specifically, I critically investigate the argument that the wearers of the modern, urban headscarf consciously underline Islamic identity through their use of the headscarf, and »sharpen their identity by labeling themselves Islamists « (Göle 1997 b: 89). How do the assumptions raised by the visibility of the headscarf unfold in the labor market for sales jobs? How do the women with headscarves respond to those assumptions, and how do they relate to the Islamic difference that is supposedly visualized by the headscarf? First, I revisit the current literature on women, Islam and headscarves in Turkey through a critical examination of the politics of difference framework. After laying out the methodological and conceptual concerns and detailing the fieldwork, I continue the critical inquiry of the dominant frameworks in the literature in light of the findings of my research. 


\section{Literature on Women, Islam and Headscarves in Turkey: The Politics of Difference Framework}

The discussion of women and Islam in Turkey took a new turn in the 199os in light of the increasing visibility of Islamist politics, and due to the rising popularity of the headscarf debate. As opposed to the inclinations to dismiss Islam as a residual influence that is supposed to wither away in the course of modernization, the increasing recognition of the influence of Islam in providing a coherent social »ethos « in Turkish society (Mardin 1986) moved religion to a more central position in social science research in Turkey. This also inspired a discussion on the effect of Islam on gender identities and gender relations, with new academic sensitivity to the potential of Islamic culture in terms of producing new discourses and ways of life in interaction with modernity.

This academic sensitivity, along with the rising interest in the increasing visibility of young, urban, educated women with headscarves in urban public spaces, spurred new research interest in women who display Islamic identity in the 1990s. There was an attempt to counter detractors of the headscarf who contended that it was » evidence " of Islamist political manipulation, a sign of false consciousness, and patriarchal oppression. In defiance of these assertions, the wearing of the headscarf increasingly started to be taken as a declaration of authentic ${ }^{1}$ identity, challenging the homogeneous and exclusionary public sphere, the hegemony of Westernization, and the traditional image of the docile Muslim woman.

Scholarship has helped to frame this debate, and there has been a remarkably strong emphasis on Islamist politics of difference and the emancipatory potential of these politics of difference for women who would define themselves as religious Muslims (Göle 1993, 1997a, 1997b, 2003, İlyasoğlu 1994, Özdalga 1997, 1998, Arat 2005). The role of the headscarf has been emphasized as the loaded symbol of politics of Islamic difference. The headscarf has been interpreted as a means of struggle for the recognition of Islamic difference as opposed to the homogenizing and exclusionary aspects of the modern, secular public sphere (Göle 1997a, Çayır 2000, Suman 2000) designated to exclude »non-Westernized Muslim population « (Göle 1997a: 65). Viewing the headscarf through the "politics of difference " framework highlights its resistance aspects, and attributes an emancipatory role to the headscarf by locating those who wear it at the center of political activism, thus provid-

1 Charles Taylor (1994) describes authenticity as the search of the modern self for an original way of being human: " There is a certain way of being human that is my way. I am called upon to live my life in this way, and not in imitation of anyone else's life. But this notion gives a new meaning to being true to myself. If I am not, I miss the point of my life; I miss what being human is for $m e$ " (Taylor 1994: 30). 
ing them with the opportunity to enter the public sphere without compromising respectability (Göle 1993). This line of argumentation also suggests that the modern, urban wearers of the headscarf bear the promise of transforming the traditional gender roles attributed to Islam by establishing moral autonomy through " conscious Muslim woman « identity.

Çayır (2000) argues that the politics of difference pursued by Islamists should be understood within the broader shift from an emphasis on equality towards recognition of difference, a trend which is increasingly apparent within social movements. Parallels are drawn between actors of new social movements, especially the feminist movement, and women wearing the headscarf (Göle 1993,1997a, Çayır 2000, Suman 2000). Nilüfer Göle also employs the term »the veiling movement « (Göle 1993: 83,1997a: 73). The analogy builds on the »difference « debate - it is argued that, similar to the second wave feminists who refused to be assimilated to the " universal « category of » human being, " and took pride in their differences, women with headscarves resist assimilation to hegemonic norms of Westernization and modernity. According to this argument, taking pride in the excluded and stigmatized headscarf symbolizes this resistance through accentuating Islamic difference (Göle 1997b, 2003, Çayır 2000, İlyasoğlu 1994), and the headscarf is argued to be the means through which religious Muslim women »sharpen their identity « and »label themselves Islamists « (Göle 1997b: 89).

The literature that frames the headscarf issue within the politics of difference discourse is undergirded by a strong focus on "cultural fissure " as the defining factor of social stratification in Turkey. Many studies which analyze the increasing visibility of Islam in the public sphere in Turkey underline the hierarchy between Islamists and secularists almost as the defining form of social stratification (Göle 1997a, 1997b, 2000, 2003, Bilici 2000, Çınar 2008, Navaro Yashin 2002). For example, Göle (2000) draws an analogy between the social stratification in Turkey and the caste system in India in order to accentuate the fissure between, what she calls, »secular and Islamist fronts « (90-91). In her account, this fissure does not manifest itself in the form of horizontal class stratification, but as a vertical stratification that cuts across classes, dividing the society as "white Turks «, which refers to the secular camp, and »others «. Bilici (2000) agrees and contends that the public sphere in Turkey is defined by status groups instead of class stratification, dominated by bureaucrats and state officers instead of the bourgeoisie. According to this argument, those who have the upper hand in this stratification maintain their cultural hegemony by excluding Islamists on the basis of cultural difference (Bilici 2000).

The lines of argumentation summarized above result in a view of the headscarf as the signifier of a collective identity constituted by a fundamental cultural difference. Nancy Fraser's criticism of the increasing focus on identity and issues of cul- 
ture in political struggles and scholarship provides a useful framework to establish a critical view of the headscarf discussion in Turkey. Fraser argues that the politics of difference discussion started as an insightful response to the »difference blindness " of the dominant liberal paradigm, but in the 8os and gos turned into a popularized tendency to focus all political claims-making on recognition of cultural difference and identity (Fraser 2000). Among the problems brought about by this exclusive focus on cultural identity, cultural difference and its recognition, is the reification of group identities. Reification of group identity, according to Fraser, "puts moral pressure on individual members to conform to a given group culture" (Fraser 2000: 112), branding criticisms to that culture as inauthentic, and obscuring intra-group power relations. Seyla Benhabib $(1999,2002)$ shares this concern and contends that the tendency to presume solid boundaries around groups and seek » recognition « for groups based on fixed identities leads to overlooking the power relations and contradictions within groups. Moreover, it leads to ignoring the complex cultural dialogue within societies. The risks involve the reification of social segregation and the formation of group enclaves (Fraser 2000).

In the case of the headscarf discussion in Turkey, focusing exclusively on »cultural difference " loads the headscarf with heavy meanings of collective identity, as pointed out by Fraser and Benhabib. This comes at the cost of essentializing and reifying an identity for women with headscarves. It also leads to overlooking nuanced negotiations around the experience of wearing the headscarf, and ignoring how differences based on class as well as social and cultural capital among women with headscarves influences this experience. It should be granted that the headscarf discussion in Turkey has been shaped along the lines of this theoretical framework for good reason. The priority was accounting for the predicaments faced by university students with headscarves who were banned from university education, and their struggle to transform the homogeneous, state monitored public sphere. Yet, whereas the context has changed towards diversified meanings of the headscarf, the literature in Turkey has remained slow and limited in responding to the transformation.

The transformation in women's experiences of displaying Islamic identity has been analyzed with regard to the accumulation of wealth among rising Islamic bourgeoisie, and the concurrent transformation from collective to individualized identities among Islamists (Çayır 2008). The most salient response of the literature on women and Islam in Turkey has been in terms of focusing closely on the changing consumption patterns of Islamic women. This focus surfaces in two kinds of analysis: first, consumption is analyzed as the realm of symbolic struggle between Islamists and secularists (Bilici 2000, Navaro-Yashin 2002). Secondly, the changing consumption patterns among Islamists are under scrutiny for they are taken to both influence and indicate the transformation of Islamism (Sandıkçı and 
Ger 2007, Gökarıksel and Secor 2010). In both analyses, the changing consumption of clothing items and flourishing personal styles among women with headscarves is a favorite theme. These analytical frameworks differ from the "politics of difference « framework because, rather than a collective identity, they focus on the diversification of Islamic woman identity, and its classification through taste (see Sandikçı and Ger 2007). Yet, these analyses are limited in the sense that there continues to be an almost exclusive focus on middle class women's experiences. Moreover, there is a resilient focus on cultural difference and its claim for a higher status with regard to society's norms, which is manifested through Islamic women's increasingly sophisticated consumption choices.

I argue that the almost exclusive focus on cultural difference displayed by middle class Islamic women in the literature stems from the resilient emphasis on cultural difference as the predominant source of constituting collectivities, as well as viewing culture based stigmatization as the predominant form of injustice in Turkey. Moreover, the focus on university educated, middle class women with headscarves, as well as Islamic intellectual and activist women, results in a limitation in terms of capturing the contested roles and meanings of the headscarf among less educated, lower middle class women.

I contend that it is necessary to critically investigate the strong focus on "politics of cultural difference « in the literature regarding women, Islam and headscarves in Turkey. I argue that the "politics of difference " framework tends to attribute loaded connotations to the headscarf and reify an identity for a supposed category of » women with headscarves «. I contend that movements pursuing politics of difference ultimately aim to render that difference as » unmarked «. Because » marks « stem from the gap between hegemonic norms in society and individuals who possess differences in their bodies, ethnic identities, clothes, and so on. Yet, the core of the criticism against politics of difference, that invests itself in the accentuation of cultural identity, is that it works against the objective of "unmarking « difference. Instead, the difference is being essentialized and reified.

This paper examines the implications of the emphasis on "group difference" for lower middle class working women with headscarves, and how they deal with the condition of being " marked «. One of the most salient themes brought up by the saleswomen with headscarves who contributed to this study as interviewees, is the desire to be unmarked. The desire to be unmarked surfaces in the face of the attributions and expectations pertaining to the "appropriate " ways in which a woman wearing a headscarf is supposed to appear and behave, as well as what she is supposed to represent in the context of the retail labor market. This paper raises questions with regard to the ways in which the literature depicts women with headscarves as a "group ", and interrogates the ways in which the headscarf is highlighted as the " mark « of this group difference. 


\section{The Structure of the Field and Methodological Concerns}

The critical inquiry of the " politics of difference « framework in this paper relies on the findings of qualitative research conducted with lower middle class saleswomen wearing the headscarf in five cities of Turkey: Gaziantep, Denizli, Kayseri, Istanbul and Ankara. The fieldwork was conducted between October 2008 and April 2012, ${ }^{2}$ and consists of focus group research, in-depth interviews, short interviews conducted with saleswomen, and participant observation. Focus groups and indepth interviews were conducted with saleswomen with and without headscarves, as well as with employers in both large and small scale retailers. Participant observation took place in different shopping settings in each city, ranging from shopping malls to traditional bazaars and tesettür stores.

The experiences of research participants with regard to the role and meaning of the headscarf in their working lives as saleswomen are central to this study. Yet, I aim to locate these experiences in relation to the structural constraints and possibilities related to wearing the headscarf in the retail labor market. Scott (1992) points out that excessive reliance on experience as »the authentic source of knowledge « bears the risk of essentializing and naturalizing identity (27). To guard against this tendency, she suggests analyzing the processes of construction of experience. In line with Scott's warning, the main methodological concern of this study is to locate the experiences of research participants with a perspective sensitive to the processes of formation of their experiences related to working life. Therefore, it is necessary to describe the field with regard to the working settings in which women with headscarves are employed as saleswomen, and from which they are excluded.

The fieldwork demonstrates that there is a demarcation among shopping settings when it comes to employing women with headscarves. Shopping malls and chain stores selling globally or nationally well known brands usually do not employ women with headscarves in sales positions. There are only a few exceptional brands and some shopping malls in which one might see women with headscarves. Still, even in shopping malls where one might see women with headscarves in sales positions, they are employed in kiosks, rather than stores. It is far more likely to see saleswomen with headscarves in small scale, family owned retailers, and tesettür chain stores. The tesettür chain store Tekbir, for example, employs women with headscarves exclusively. Compared to small scale retailers, chain stores and shopping malls offer sales staff better chances of career advancement and social

2 Part of the research was funded by TUBITAK, and was conducted by myself and two professors, Dr. Dilek Cindoğlu and Dr. Aslı Çırakman. From 2009 on, I proceeded with my own fieldwork for my dissertation. 
security, as well as more flexible working hours. Working in a small scale retailer, on the other hand, is more often than not, defined by approximately 12 hour working days, if not longer, with no lunch break and only one day off in two weeks. Sales jobs in small scale retailers tend to not offer the chances of professional advancement, in contrast to chain stores where it is possible to become a branch manager, or seek employment in higher echelons of management in retail. More often than not, saleswomen working in small scale retailers work without social security. As of April 2012, the average salary of a saleswoman working in a small scale retailer in a central bazaar in Istanbul was around 600 TL (approximately 220 Euros), whereas the minimum wage is $700 \mathrm{TL}$.

The narratives of saleswomen with headscarves are replete with stories of being refused employment by large scale retailers and shopping malls. In many cases, they are explicitly told that the headscarf is the reason of their rejection. The general manager of a major shopping mall in Istanbul explained to me in an in-depth interview that in the shopping mall he manages, women with headscarves are not employed as saleswomen. Actually, he put it in other terms: He said that they may be employed, on the condition that they agree to take off their scarf during working hours. However, women can work with their headscarves on as cleaning ladies in the malls. The saleswomen with headscarves who participated in this research worked either in small scale retailers, or tesettür chain stores, particularly Tekbir and Setrms. Similar to their colleagues in large scale retailers, the women working in tesettür stores were insured, and had better working conditions in terms of working hours, wages, and career prospects.

The majority of the saleswomen with headscarves who participated in the research were either 8-year elementary school or high school graduates, with an income lower than the minimum wage. Almost all of them represented the first generation of women in their families who worked outside home.

\section{The Findings and How They Relate to "Difference"}

The findings of this research highlight the discontent of saleswomen with headscarves as a result of being marked out as different, and the commensurate stereotypes that go along with wearing the headscarf. They particularly tried to distance themselves from the expectation that they should display a coherent religious identity devoid of contradictions. Fatma Barbarosoğlu, an Islamist intellectual female writer, defines the symbolic meaning of the headscarf as »the project of perfection « (Şişman 2000: 15). » The project of perfection « refers to the notion that a woman who wears a headscarf should necessarily and by definition adhere unerringly to Islamic precepts. Moreover, according to Barbarosoğlu, a woman 
with a headscarf should be aware that every attitude she displays is potentially attributed to the collectivity of women with headscarves. The kind of religiosity Barbarosoğlu expects from women with headscarves reflects the well known argument that Islamic faith is not just a matter of what one believes. Rather, it is about cultivating an Islamic way of living (Saktanber 2002). Barbarosoğlu's use of the concept » the project of perfection « encapsulates the belief that the headscarf necessarily connotes deeply rooted religiosity that permeates one's life and identity to its core. The concept " project of perfection « also highlights how essential it is for women with headscarves to underline that they are different from secular women in the public realm. The concept is particularly interesting for the purposes of this paper, not only because it points to widespread expectations from women with headscarves, but also because it highlights exactly the kind of essentialization of identity that many participants of this research found frustrating.

Among the salient themes permeating the research data was discontent with being judged with regard to the expectations raised by the visibility of the headscarf. These expectations, ranging from the expectation that a woman with a headscarf performs the prayers, to abiding fully by rules of tesettür clothing, were found confining. The frustration with these expectations especially surfaced at points where the perceived necessities of working life made it difficult to fulfill them.

Pinar $^{3}$ was among the participants who voiced such discontent. She is a 23-year-old married woman selling lingerie at a narrow counter in the entrance of a crowded and lively arcade in Denizli. She expressed the idea that the expectations raised by the headscarf sometimes contradicted the necessities of business:

People expect covered women to be honest all the time. Maybe because they think our religious conviction is stronger. They do not want us to lie at all. Of course I do not lie, but there may be times when I do not tell the full truth. For example, if there is a cheaper product and a more expensive one and they are both of the same quality, I try to sell the more expensive one. This is called business. We are doing business here. I grew up in this business, and this is how I learned.

Pinar's honest declaration reflects her frustration with the gap between what people expect her to be and the flexibility she needs in order to »do business «. A similar sentiment was voiced by many other participants, who thought that displaying "perfect religiosity « was expected only from them, and not from men, who would call themselves religious Muslims. Moreover, what constitutes »perfect re-

3 The names of the participants used in this essay are pseudonyms in order to protect anonymity. 
ligiosity « was defined without taking into account their experiences. It was as if the visibility of the headscarf made them responsible for leading an Islamic life and setting examples of how to be a religious Muslim, a responsibility that they found constraining. This sense of constraint was also reflected in the discrimination they faced in their search for jobs as saleswomen. Many respondents thought that some employers did not want to employ them because of certain assumptions: for example, according to one respondent, employers thought that when a woman is covered, she would refrain from communication and would be silent and reclusive. Another respondent said that the headscarf was assumed to indicate that the woman wearing it would be incapable of giving advice on fashion. Or, at least, the customers would not take their advice seriously. This assumption was confirmed by some of the employers who participated in the research. What was more interesting was that even those employers who have many customers with headscarves hold these kinds of assumptions as well. Another assumption among employers was that a saleswoman wearing a headscarf would alienate customers because the store would lose its » neutral «, that is, » unmarked « stance.

The role of the headscarf in terms creating a » mark of difference « on those who wear it has been analyzed before with regard to how it subjugates women to the public gaze (Çınar 2008). It has also been argued that women with headscarves are labelled as "overly religious « and perceived as declaring their non-neutrality - excluding them from the image of " unaffiliated « or " productive modern citizens « (Gökariksel and Mitchell 2005: 150-151). The assumptions of employers about women with headscarves are in line with these arguments. Yet, rather than looking into why employers hold these assumptions, this paper aims to put the focus on how, and through what kind of discursive strategies, women with headscarves respond to these categorizations and assumptions.

The findings of the research indicate that one of the most popular ways of responding to these assumptions is to mitigate the loaded connotations of the headscarf by arguing that some women may cover their head to declare an »overly religious « identity, but that that is not their own intention. This response surfaces in narratives which develop a fragmented conception of the practice of covering defined in terms of »degrees «. According to this conception, only some women are » fully covered « (tam kapal). The concept of »fully covered «, which appears in the narratives of many participants of the research, refers to women who exclusively wear long overcoats, big headscarves, or chadors, and who avoid interaction with men. More often than not, the participants of the research tended to distance themselves from the "fully covered ", and sometimes referred to themselves as " half covered, « as opposed to » fully covered «. One of the participants who emphasized her distinction from the "fully covered « was Zarife, an 18 year old single woman working in a pastry shop in Istanbul, Bayrampaşa: she donned the head- 
scarf at the age of 11, and emphasized that she wears the headscarf » only for God, « as opposed to those " who just want to show off with their headscarves ", or those who cover »because of family pressure «. Before the pastry shop, she had worked as an assistant in a pharmacy for two years, but when the pharmacy went out of business, her job applications to other pharmacies were turned down. She strongly believes that she was discriminated against due to the headscarf. She was aggrieved by this because she thought that working in a pastry shop was a loss of status compared to working in a pharmacy. As a young single woman who wanted to find her future husband herself, and not through arranged marriage, she was also disappointed with boys of her age who would refrain from talking to her, as they assumed she would stay away from friendship with boys. She emphasized that she liked socializing, going to cafes, seeing movies, enjoyed having friendly relations with boys, just like her uncovered friends, and did not want to be regarded as different from them. She had a particularly memorable way of formulating the degree of her religiosity:

- My religiosity is the size of a teaspoon.

- Why, what does that mean?

- If I were a tablespoon ... I mean if I had devoted myself to my religion completely, if I had not been working, I could have done it with a tablespoon. I could even have done it with a ladle. But I cannot imagine myself in a chador.

- So being religious with a ladle means wearing the chador?

- Yes, with the face veil and gloves and all. They do not talk to men. That seems a little ridiculous. I would not like to be like that.

- Then you are happy with your teaspoon of religiosity?

- Yes I am, very happy.

- And you want to go on like this?

- Maybe I could do a little more than the teaspoon. But not too much more ... I would not take on the chador. Imagine when it is summer, the sun will come out, it gets so hot (chuckles).

Even though she defined her religiosity as a "teaspoon «, for Zarife taking off the headscarf was not an option, as she thought of it as an inseparable part of her religious conviction. This was not the case with all the research participants. Some thought that the headscarf could be negotiated, especially in order to find employment in public sector jobs. Selin, a 21-year old single woman working in a tesettür store in Denizli, was one of them. Similar to Zarife, Selin was also disappointed with the status of her job as her real aspiration was to become a policewoman, and she was ready to take off her headscarf in order to reach that aspiration. She took the exams to become a policewoman, but failed. Afterwards, she 
took off her headscarf in order to work in a private security company. However, she realized that the job in that private security company did not offer any career prospects, therefore it was "not worth uncovering ". Following her experience at the security company, she put her headscarf back on and applied for her current job in the tesettür chain store, where she was immediately hired. She felt lucky to have found a sales job in a tesettür chain store, which has much better conditions than sales jobs in small scale retailers. This job pays almost as well as the job in the private security company, and she has social security as well. While explaining her choice of uncovering for a job that is "worth it «, she referred to her religiosity as »belief in the inside «:

- My dream was to be a policewoman. I took the exams. For those exams I took my headscarf off, I even had to show my legs and arms of course, because in those interviews they have to look at your body ... You have to do this stuff to become someone.

- You did not become a policewoman?

- No, I could not pass the exams.

- But if you became one, you would take off your headscarf?

- Of course I would. My family may be covered people but we are not of those people who think that religion is in the headscarf. It is something inside of you. It is not about covering on the outside, it is about belief in the inside.

Selin did not want to be misunderstood as someone who bargains her religiosity for a career. Therefore, in her narrative it is possible to see the effort to break the perceived link between religiosity and the headscarf in order to make the point that taking off the headscarf does not mean compromising religiosity. This is why she distances herself from those " who think that religion is in the headscarf «, and formulates her religiosity as » religiosity in the inside «. The tendency to decouple the headscarf from the meanings attributed to it was a common tendency among the research participants. This tendency should be analyzed with regard to the context of their working lives, in which the women with headscarves feel discriminated against in their search for employment and excluded from jobs with better career prospects due to the headscarf and the essentialist meanings attributed to it.

Besides the effort to distance themselves from the "fully covered « and to further distance the headscarf that they themselves wear from the assumed meanings, the research participants also displayed the tendency to emphasize blurred lines between the states of » being covered « and »being uncovered «. Selin underlined that she was » not born with a headscarf«:

People seem to think that we were born with headscarves. It is so strange ... It is a matter of respect, I respect uncovered people and they should respect me. Because this 
headscarf actually has no function, it is just something I prefer. You may put it on or not. And some of those who wear it are not even modest either ... What I mean is that, these are just periods for me: I passed through an uncovered period now I am in a covered period.

Selin's expression of how the headscarf is $»$ just something she prefers, with no function « is a crystallized expression of a common pattern among research participants' narratives which points out the tendency to formulate the headscarf as just a choice of clothing among many other choices. Zübeyde, a 21 year old married woman selling women's clothes in a clothing shop in Denizli, thought that the headscarf was only an indicator of modesty and >ladylike behaviour «. She contended that taking it off on some special days would not compromise her modesty, as long as she was careful about her behaviour, and did not wear miniskirts and low-cut blouses.

I am covered, but for example, I will take off the headscarf for my sister-in-law's wedding. We are not covered that solidly, me and my family. There are some families ... once covered, they do not accept uncovering. That is not the case for me ... This is like a matter of taste. Some like this kind of skirt, some like it shorter, some like it longer. Covering is like that for me.

Similar to Selin, Zübeyde also refers to her headscarf as only a matter of taste, a choice of clothing among many other choices, such as choosing this or that length of a skirt. Actually, the length of a skirt is not devoid from socially loaded meanings either. Yet, the point is that, both Selin and Zübeyde tend to stay away from any »load « attributed to the headscarf, which may result in rendering them »different « from what they perceive as the mainstream and socially accepted norms of modest womanhood. Instead of underlining and highlighting a »difference" of identity implied by the headscarf, they subscribe to a discourse that defends "convergence « towards the image of a woman who behaves and dresses modestly. This image includes women without headscarves as well, but on the condition that they abide by certain norms of modesty. Defining norms of modesty is a very contested issue among women with headscarves, as manifested in categorizations such as »fully covered « vs. »half covered «. Zübeyde introduces another categorization: those who are »solidly covered « and will not take it off once they wear it, and those who may take off the headscarf on special days, or for the sake of higher status jobs, »to become somebody « as Selin puts it. At this point it is necessary to emphasize that not all research participants were as comfortable with the idea of taking off their headscarves on occasion as Selin and Zübeyde. Some participants said their families and relatives would take it very badly in case they at- 
tempted to uncover. Others also scorned the attitude of taking the headscarf on and off and regarded it as an indicator of weak conviction. Even though these differences in the issue of » uncovering " signify important fault lines among women with headscarves, it should be underlined that the overarching pattern among research participants was to complain about and avoid what they found to be essentializing and confining assumptions about the headscarf.

\section{Conclusion}

In this paper, I have discussed how the assumption that the headscarf should connote an Islamic identity and difference unfolds in the lives of lower middle class women without a university degree in the context of their working lives. With reference to the theoretical discussion on the politics of difference and to the research findings, I have critically investigated the argument that the headscarf is a way of asserting an Islamic identity and declaring >difference against the grain of the homogenizing public sphere. I have looked into how the lower middle class, working saleswomen with headscarves relate to the discourse of difference and whether they view their headscarves as an assertion of identity and difference. The research findings indicate that, in contrast to the arguments found in a large body of literature on women and Islam in Turkey, which view the issue through a politics of different framework, the participants of the research found it difficult to accept many of the connotations attributed to the headscarf. There was a strong tendency to avoid a discourse of difference by underlining that wearing the headscarf has a contingent, not essential or absolute, meanings in their lives. Rather than constructing their identity by wearing the headscarf, the motivation was to decouple the presumed links between cultural and religious difference and the headscarf.

\section{References}

Arat, Yeşim. Rethinking Islam and liberal democracy: Islamist women in Turkish politics. Albany: State University of New York Press, 2005.

Benhabib, Seyla. 1999. » The liberal imagination and the four dogmas of multiculturalism. "The Yale Journal of Criticism 12,2: 401-13.

Benhabib, Seyla. The claims of culture: Equality and diversity in the global era. Princeton: Princeton University Press, 2002.

Bilici, Mücahit. 200o. »İslam’ın bronzlaşan yüzü: Caprice Hotel örnek olayı. «In İslamın yeni kamusal yüzleri, edited by Nilüfer Göle, 216-236. Istanbul: Metis.

Çayır, Kenan. 200o. »İslamcı bir sivil toplum örgütü: Gökkuşağı İstanbul kadın platformu. « In İslamın yeni kamusal yüzleri, edited by Nilüfer Göle, 41-67. Istanbul: Metis. 
Çayır, Kenan. Türkiye'de İslamcılık ve İslami edebiyat: Toplu hidayet söyleminden yeni bireysel Müslümanlıklara. Istanbul: İstanbul Bilgi Üniversitesi Yayınları, 2008.

Çinar, Alev. 2008. »Subversion and subjugation in the public sphere: Secularism and the Islamic headscarf. «Signs: Journal of Women in Culture and Society 33,4: 891-913.

Fraser, Nancy. 2000. »Rethinking recognition. « New Left Review 3, May-June 2000.

Gökarıksel, Banu, Mitchell Katheryne. 2005. "Veiling, secularism, and the neoliberal subject: National narratives and supranational desires in Turkey and France. « Global Networks 5,2: 147-165.

Gökarıksel, Banu, Secor, Anna. 2010. »Between fashion and tesettür: Marketing and consuming women's Islamic dress. "Journal of Middle East Women's Studies 6,3: 118-148.

Göle, Nilüfer. Modern mahrem: Medeniyet ve örtünme. Istanbul: Metis, 1993.

Göle, Nilüfer. 1997a. »The gendered nature of the public sphere. «Public Culture 10,1: 61-81.

Göle, Nilüfer. 1997b. »The quest for the Islamic self within the context of modernity. «In Rethinking modernity and national identity in Turkey, edited by Sibel Bozdoğan and Reşat Kasaba, 81-95. Seattle and London: University of Washington Press.

Göle, Nilüfer. 200o. »İslami dokunulmazlar, laikler ve radikal demokratlar. «In Melez desenler, 88-96. Istanbul: Metis.

Göle, Nilüfer. 2003. »The voluntary adoption of Islamic stigma symbols. « Social Research 70,3: 809-828.

İlyasoğlu, Aynur. Örtülü kimlik: İslamcı kadın kimliğinin oluşum öğeleri. Istanbul: Metis, 1994.

Mardin, Şerif. 1986. "Religion and politics in modern Turkey. «In Islam in the political process, edited by J.P. Piscaton. Cambridge: Cambridge University Press.

Navaro-Yashin, Yael. Faces of the state: Secularism and public life in Turkey. Princeton and Oxford: Princeton University Press, 2002.

Özdalga, Elizabeth. 1997. »Womanhood, dignity and faith: Reflections on an Islamic woman's life story. « European Journal of Women's Studies 4: 473-497.

Özdalga, Elizabeth. The veiling issue, official secularism and popular Islam in Turkey. Surrey: Curzon Press, 1998.

Saktanber, Ayşe. Living Islam: Women, religion and the politicization of culture in Turkey. London \& New York: I. B. Tauris, 2002.

Sandıkçı, Özlem, Ger, Güliz. 2007. »Constructing and representing the Islamic consumer in Turkey. "Fashion Theory 11,2/3: 189-210.

Scott, Joan W. 1992. »Experience. «In Feminists theorize the political, edited by Judith Butler and Joan W. Scott, 22-40. New York, London: Routledge.

Suman, Defne. 2000. »Feminizm, İslam ve kamusal alan. «In İslamın yeni kamusal yüzleri, edited by Nilüfer Göle. Istanbul: Metis.

Şişman, Nazife. Kamusal alanda başörtülüler: Fatma Karabıyık Barbarosoğlu ile söyleşi. Istanbul: İz Yayıncılık, 2000.

Taylor, Charles. 1994. " The politics of recognition. "In Multiculturalism: A critical reader, edited by David Theo Goldberg. Oxford \& Cambridge: Blackwell.

White, Jenny. 2005. "The paradox of the new Islamic woman in Turkey. «In Gender, religion and change in the Middle East: Two hundred years of history, edited by Inger Marie Okkenhaug and Ingvild Flaskerud. UK: Berg.

Open Access. This chapter is distributed under the terms of the Creative Commons Attribution Noncommercial License, which permits any noncommercial use, distribution, and reproduction in any medium, provided the original author(s) and source are credited. 